\title{
Exogenous hydrogen sulfide exerts proliferation, anti-apoptosis, angiopoiesis and migration effects via activating HSP90 pathway in EC109 cells
}

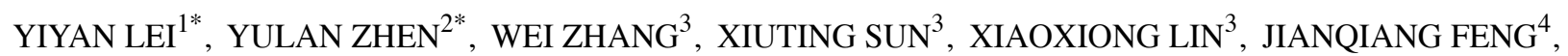

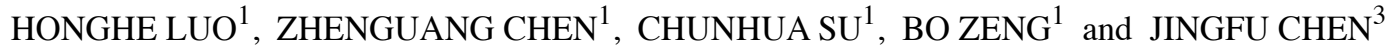 \\ ${ }^{1}$ Department of Thoracic Surgery, The First Affiliated Hospital, Sun Yat-sen University, Guangdong, Guangzhou 510080; \\ ${ }^{2}$ Department of Oncology, The Affiliated Hospital, Guangdong Medical College, Zhanjiang, Guangdong 524001; \\ ${ }^{3}$ Department of Cardiovasology and Cardiac Care Unit (CCU), Huangpu Division of The First Affiliated Hospital, \\ Sun Yat-sen University, Guangdong, Guangzhou 510700; ${ }^{4}$ Department of Physiology, \\ Zhongshan School of Medicine, Sun Yat-sen University, Guangzhou 510080, P.R. China
}

Received December 20, 2015; Accepted January 27, 2016

DOI: $10.3892 /$ or.2016.4734

\begin{abstract}
Hydrogen sulfide $\left(\mathrm{H}_{2} \mathrm{~S}\right)$ participates in diverse physiological and pathophysiologic processes of cancer both in vitro and in vivo. We have previously reported the proliferation/ anti-apoptosis/angiogenesis/migration effects of exogenous $\mathrm{H}_{2} \mathrm{~S}$ on liver cancer and glioma via amplifying the activation of NF- $\kappa \mathrm{B}$ and $\mathrm{p} 38 \mathrm{MAPK} / \mathrm{ERK} 1 / 2-\mathrm{COX}-2$ pathway. However, the effects of $\mathrm{H}_{2} \mathrm{~S}$ on EC109 esophageal cells remain unclear. The present study demonstrated the effects of exogenous $\mathrm{H}_{2} \mathrm{~S}$ on cancer cell growth via activating HSP90 pathways in EC109 esophageal cells. EC109 esophageal cells were treated with $400 \mu \mathrm{mol} / 1 \mathrm{NaHS}$ (a donor of $\mathrm{H}_{2} \mathrm{~S}$ ) for $24 \mathrm{~h}$. The expression levels of HSP90, bcl-2, caspase-3, bax and MMP-2 were detected by western blot assay. Cell viability was detected by Cell Counting Kit-8 (CCK-8). The migration rate was analyzed using a Transwell migration assay and ImageJ software. NaHS promoted cell proliferation, as evidenced by an increase in cell viability. In addition, NaHS treatment reduced apoptosis, as indicated by the increased bcl- 2 expression and decreased cleaved caspase- 3 and bax expression. Importantly, exposure of NaHS increased the expression of MMP-2, the migration rate and expression of VEGF. Notably, co-treatment of EC109 cells with NaHS and GA (an inhibitor of HSP90 pathway)
\end{abstract}

Correspondence to: Dr Bo Zeng, Department of Thoracic Surgery, The First Affiliated Hospital, Sun Yat-sen University, Guangdong, Guangzhou 510080, P.R. China

E-mail: zengbo113@163.com

Dr Jingfu Chen, Department of Cardiovasology and Cardiac Care Unit (CCU), Huangpu Division of The First Affiliated Hospital, Sun Yat-sen University, Guangdong, Guangzhou 510700, P.R. China

E-mail: chenjf-sums@hotmail.com

*Contributed equally

Key words: hydrogen sulfide, EC109 cells, HSP90 pathway, growth largely suppressed the aforementioned NaHS-induced effects. The findings of the present study provided novel evidence that HSP90 pathway was involved in NaHS-induced cancer cell proliferation, anti-apoptosis, angiopoiesis and migration in EC109 esophageal cells.

\section{Introduction}

Esophageal cancer (EC), ranked as the sixth leading cause of cancer-related mortality worldwide, is one of the most highly malignant and aggressive cancers $(1,2)$. Esophageal squamous cell carcinoma (ESCC) is the predominant histological subtype, accounting for more than $90 \%$ of EC cases in China (3). Although screening technology and multimodality therapies have remarkably improved during the past decade, the prognosis of EC remains dismal and the 5-year overall survival rate is still below $15 \%$ (4). Accumulative studies have tried to demonstrate the molecular and biological mechanisms that lead to EC. A series of risk factors for EC have been established, such as epidermal growth factor receptor (EGFR), Her-2, p53 and heat shock proteins (HSPs), which have been found to be associated with the progression of EC (5-8). However, the mechanisms of oncogenesis of EC have not been completely clarified. Therefore, the characterization of molecular markers involved in the pathophysiological process of ESCC is essential.

The HSPs family, as molecular chaperones, are biochemical regulators, which function in mediating cell growth, apoptosis, migration and protein homeostasis (9). HSPs are induced in response not only to cellular stress, but also to other environmental, physical and chemical stresses (10). HSPs are classified into 6 major family members according to molecular weight: HSP100, HSP90, HSP70, HSP60, HSP40 and small HSPs (11). HSP90 is one of the most abundant HSPs and more than 200 types of HSP90 client proteins have been found. A series of previous studies have demonstrated that HSP90 is activated and upmodulated in a wide variety of human tumors, such as head and neck squamous cell cancer (HNSCC) (12), 
colon carcinoma (13) and other adenocarcinomas (14). During the progression of cancers, HSP90 has a key role in the regulation of cell cycle growth, signaling, migration and transcription factors, which may lead to tumorigenesis (15-17). However, there is a paucity of data on the relationship between activation of HSP90 and the malignancy of EC.

Hydrogen sulfide $\left(\mathrm{H}_{2} \mathrm{~S}\right)$, as a specific toxic gas, has been qualified as the third gasotransmitter following nitric oxide (NO) and carbon monoxide (CO) (18-20). Endogenous $\mathrm{H}_{2} \mathrm{~S}$ is synthesized from L-cysteine by two key enzymes: cystathionine- $\beta$-synthase (CBS) and cystathionine- $\gamma$-lyase (CSE) which are mainly expressed in the enteric neurons and smooth muscle of the stomach and colon $(21,22)$. Recently, numerous scientific investigations have proven the extensive physiological and pathophysiological properties of $\mathrm{H}_{2} \mathrm{~S}$ on progress of cancer. Previous findings have demonstrated that $\mathrm{H}_{2} \mathrm{~S}$ promotes cancer cell growth, proliferation, migration and invasion (23-29), owing to its vascular relaxant and angiogenesis effects. $\mathrm{H}_{2} \mathrm{~S}$ enhances the supply of nutrients and blood to the tumor cells and tissues (29). Our latest research also showed that exogenous $\mathrm{H}_{2} \mathrm{~S}$ promoted cancer cell proliferation/antiapoptosis/angiogenesis/migration effects via amplifying the activation of NF- $\kappa \mathrm{B}(30)$ and $\mathrm{p} 38 \mathrm{MAPK} / \mathrm{ERK} 1 / 2-\mathrm{COX}-2$ pathways (31). However, research focused on the effect of exogenous $\mathrm{H}_{2} \mathrm{~S}$ on esophageal EC109 cells and its potential mechanisms is lacking. Hence, we investigated whether exogenous $\mathrm{H}_{2} \mathrm{~S}$ contributes to cancer progress and explored these potential effects via activation of HSP90 pathways in esophageal EC109 cells.

\section{Materials and methods}

Materials. NaHS, a donor of $\mathrm{H}_{2} \mathrm{~S}$, was obtained from Sigma Chemicals Co. (St. Louis, MO, USA), stored at $2-4^{\circ} \mathrm{C}$ and protected from sunlight. GA (a specific inhibitor of HSP90 pathway) was also purchased from Sigma Chemicals Co. The Cell Counting Kit-8 (CCK-8) was supplied by Dojindo Laboratory (Kumamoto, Japan). Fetal bovine serum (FBS) and RPMI-1640 medium were obtained from Gibco-BRL (Grand Island, NY, USA). Anti-MMP2, anti-HSP90, anti-cleaved caspase-3, anti-bcl-2 antibody and anti-bax antibodies were supplied by Cell Signaling Technology (Boston, MA, USA). Horseradish peroxidase (HRP)-conjugated secondary antibody and BCA protein assay kit were obtained from KangChen Bio-tech, Inc. (Shanghai, China). Enhanced chemiluminescence (ECL) solution was purchased from KeyGen Biotech (Nanjing, China). Enzyme-linked immunosorbent assay (ELISA) was supplied by ExCell Bio Co. (Shanghai, China).

Cell culture and treatments. The human esophageal carcinoma cells EC109 (EC109 cells) were supplied by Sun Yat-sen University Experimental Animal Center (Guangzhou, Guangdong, China). The EC109 cells were grown in RPMI-1640 medium supplemented with 10\% FBS under an atmosphere of $5 \% \mathrm{CO}_{2}$ and at $37^{\circ} \mathrm{C}$ with $95 \%$ air. The $\mathrm{EC} 109$ cells were treated with $500 \mu \mathrm{mol} / 1 \mathrm{NaHS}$ for $24 \mathrm{~h}$ or co-treated with $500 \mu \mathrm{mol} / 1 \mathrm{NaHS}$ and $20 \mu \mathrm{mol} / 1 \mathrm{GA}$ for $24 \mathrm{~h}$.

Western blot analysis. After the indicated treatments, the cells were harvested and lysed with cell lysis solution at $4^{\circ} \mathrm{C}$ for
$30 \mathrm{~min}$. The total proteins were quantified using the BCA protein assay kit. Loading buffer was added to cytosolic extracts, and then after boiling for $6 \mathrm{~min}$, the same amounts of supernatant from each sample were fractionated by $10 \%$ sodium dodecyl sulphate-polyacrylamide gel electrophoresis (SDS-PAGE). The total proteins were then transferred into polyvinylidene difluoride (PVDF) membranes. The membranes were blocked with $5 \%$ fat-free milk for $60 \mathrm{~min}$ in fresh blocking buffer [0.1\% Tween-20 in Tris-buffered saline (TBS-T)] at room temperature, and incubated with either anti-MMP2 (1:1,000 dilution), anti-HSP90 (1:1,000 dilution), anti-bax (1:1,000 dilution), anti-bcl-2 (1:1,000 dilution) and anti-cleaved caspase-3 antibodies (1:1,000 dilution) in freshly prepared TBS-T with 3\% fat-free milk overnight with gentle agitation at $4^{\circ} \mathrm{C}$. Membranes were washed for $5 \mathrm{~min}$ with TBS-T for 3 times and incubated with HRP-conjugated goat anti-rabbit secondary antibody at a concentration of 1:3,000 dilution (Kangchen Biotech, Shanghai, China), in TBS-T with $3 \%$ fat-free milk for $1.5 \mathrm{~h}$ at room temperature. Then, membranes were washed 3 times with TBS-T for $5 \mathrm{~min}$. The immunoreactive signals were visualized via the ECL. In order to quantify the protein expression, the X-ray film was scanned and analyzed with ImageJ $1.47 \mathrm{i}$ software. The experiment was carried out 3 times.

Measurement of cell viability. The EC109 cells were seeded in 96-well plates at some concentration of $1 \times 10^{4} / \mathrm{ml}$ and incubated at $37^{\circ} \mathrm{C}$. The CCK-8 assay was employed to assess the cell viability of EC109 cells. After the indicated treatments, $10 \mu \mathrm{l}$ CCK-8 solution at a $1 / 10$ dilution was added to each well and then the plate was incubated for $1.5 \mathrm{~h}$ in the incubator. Absorbance at $450 \mathrm{~nm}$ was assayed using a microplate reader (Molecular Devices, Sunnyvale, CA, USA). The means of the optical density (OD) of 3-wells in the indicated groups were used to calculate the percentage of cell viability according to the formula below: Cell viability $(\%)=(\mathrm{OD}$ treatment group/OD control group) $\mathrm{x} 100 \%$. The experiment was carried out 5 times.

ELISA for detection of VEGF in culture supernatant. EC109 cells were cultured in 96-well plates. After the different indicated treatments, the level of VEGF in the culture media was tested by ELISA according to the manufacturer's instructions. The experiment was performed at least 5 times.

Transwell migration assay. The EC109 cells were harvested and washed twice with phosphate-buffered saline (PBS). After washing, $1 \times 10^{5}$ cells were resuspended in $200 \mu \mathrm{l}$ Dulbecco's modified Eagle's medium (DMEM), and added to the upper chamber of the Transwell membrane (Transwell permeable support with a $5.0-\mu \mathrm{m}$ polycarbonate membrane, $6.5-\mathrm{mm}$ insert and 24-well plate; Corning Costar, Tewksbury, MA, USA), and $600 \mu \mathrm{l}$ of $10 \%$ FBS-DMEM was added to each bottom chamber. Four groups in the upper chamber were included in the assay: i) control; ii) $\mathrm{NaHS}, \mathrm{NaHS}(500 \mu \mathrm{mol} / \mathrm{l})$; iii) NaHS + GA (a specific inhibitor of HSP90 pathway), NaHS $(500 \mu \mathrm{mol} / \mathrm{l})+\mathrm{GA}(20 \mu \mathrm{mol} / \mathrm{l})$; iv) GA, GA $(20 \mu \mathrm{mol} / \mathrm{l})$. After $24 \mathrm{~h}$ at $37^{\circ} \mathrm{C}$, cells that migrated to the lower chambers were counted. Triplicate experiments were performed with each group, and the means and standard deviations were calculated. 

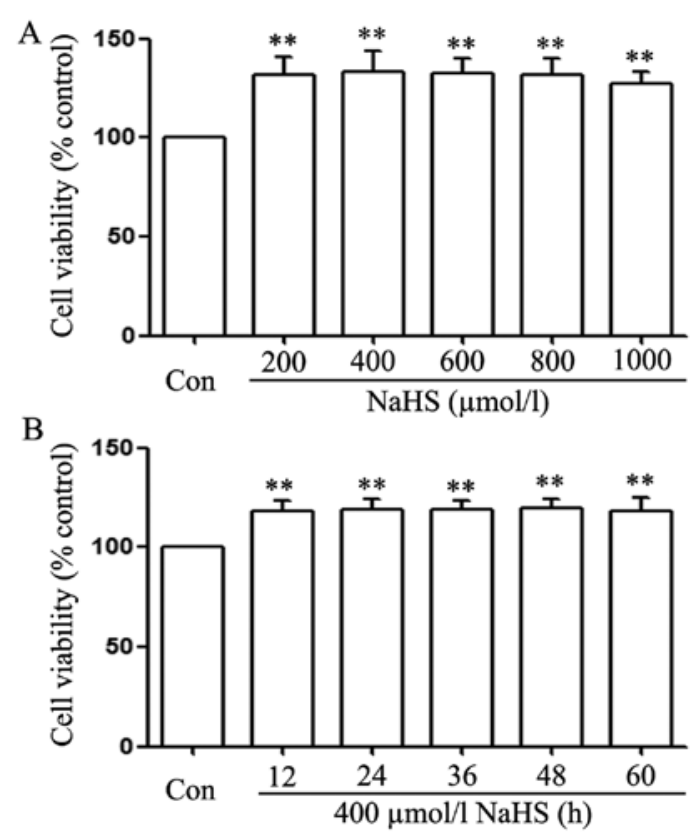

Figure 1. NaHS promotes cell proliferation in EC109 cells. Cell viability was tested using the Cell Counting Kit-8 (CCK-8). (A) EC109 cells were treated with different doses of NaHS $(200,400,600,800$ and $1,000 \mu \mathrm{mol} / 1)$ for $24 \mathrm{~h}$. (B) Cells were treated with $400 \mu \mathrm{mol} / 1 \mathrm{NaHS}$ for the indicated times (12, 24, $36,48$ and $60 \mathrm{~h})$. Data are the mean $\pm \operatorname{SEM}(\mathrm{n}=3) .{ }^{* *} \mathrm{P}<0.01$ compared with the control group. Con, the control group; NaHS, a donor of $\mathrm{H}_{2} \mathrm{~S}$.

A

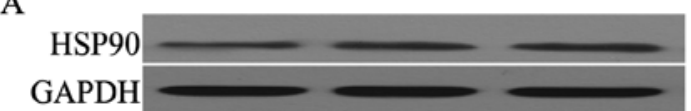

B

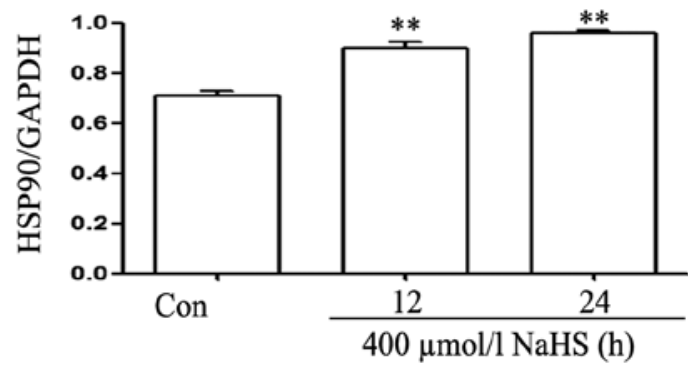

Figure 2 (A and B). NaHS upregulates the expression levels of HSP90 in EC109 cells. EC109 cells were exposed to $400 \mu \mathrm{mol} / 1 \mathrm{NaHS}$ for the indicated times (12 and $24 \mathrm{~h}$ ). The expression levels of HSP90 were measured by western blot analysis. The data were quantified by densitometric analysis with ImageJ $1.47 \mathrm{i}$ software. Data are shown as the mean $\pm \operatorname{SEM}(n=3) .{ }^{* *} \mathrm{P}<0.01 \mathrm{vs}$. the control group; Con, the control group; NaHS, a donor of $\mathrm{H}_{2} \mathrm{~S}$.

Statistical analysis. All data are presented as the mean \pm SEM. Differences between groups were analyzed by one-way analysis of variance (ANOVA) using SPSS 13.0 (SPSS, Inc., Chicago, IL, USA) software, and followed by LSD post hoc comparison test. Statistical significance was considered at $\mathrm{P}<0.05$.

\section{Results}

NaHS promotes cell proliferation in EC109 esophageal cells. In order to test the effect of exogenous $\mathrm{H}_{2} \mathrm{~S}$ on human EC cell proliferation, the dose-response study with varying doses
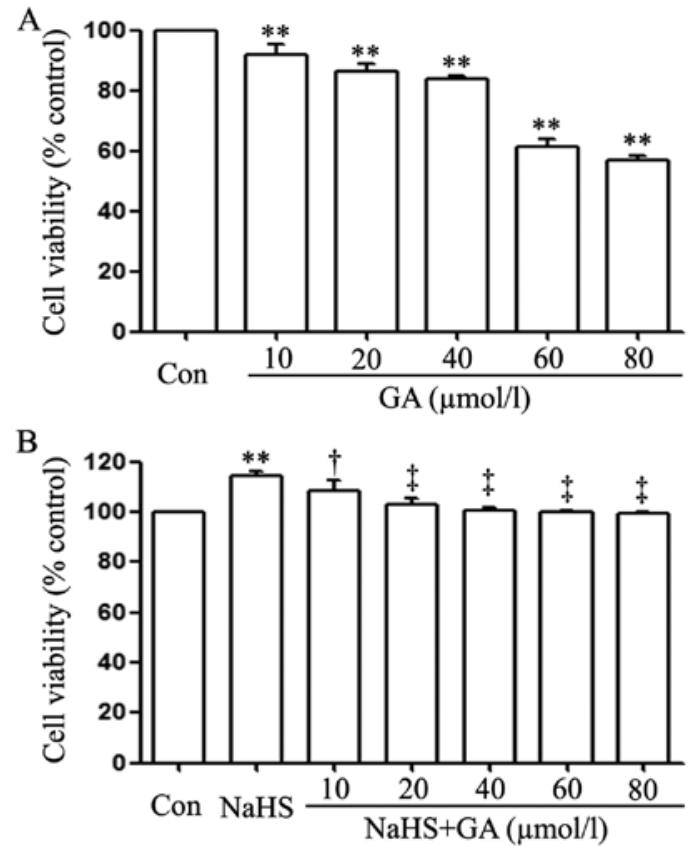

Figure 3. (A) GA reduces the cell proliferation in EC109 cells. EC109 cells were treated with different doses of GA $(10,20,40,60$ and $80 \mu \mathrm{mol} / \mathrm{l})$ for 24 h. (B) GA alleviates NaHS-induced cell proliferation in EC109 cells. EC109 cells were co-conditioned with $400 \mu \mathrm{mol} / 1 \mathrm{NaHS}$ and different doses of GA $(10,20,40,60$ and $80 \mu \mathrm{mol} / \mathrm{l})$ for $24 \mathrm{~h}$. Data are the mean $\pm \mathrm{SEM}$ $(\mathrm{n}=3) .{ }^{* *} \mathrm{P}<0.01$ compared with the control group ${ }^{++} \mathrm{P}<0.01$ compared with the NaHS group. Con, the control group; $\mathrm{NaHS}$, a donor of $\mathrm{H}_{2} \mathrm{~S}$; GA, a specific inhibitor of the HSP90 pathway.

(200, 400, 600, 800 and 1,000 $\mu \mathrm{mol} / \mathrm{l}$ ) of NaHS (a donor of $\mathrm{H}_{2} \mathrm{~S}$ ) for $24 \mathrm{~h}$ was performed to calculate the effective doses of NaHS. As shown in Fig. 1A, the doses of NaHS from 200 to $1,000 \mu \mathrm{mol} / 1$ markedly promoted cell proliferation, leading to an increase in cell viability and reaching a peak at $400 \mu \mathrm{mol} / 1$. Therefore, $400 \mu \mathrm{mol} / 1 \mathrm{NaHS}$ was used in the subsequent time-response study with different treatment times $(12,24,36$, 48 and 60 h). As shown in Fig. 1B, treatment of EC109 cells with $400 \mu \mathrm{mol} / 1 \mathrm{NaHS}$ for the indicated times all markedly promoted cell proliferation, reaching the maximal proliferative effect at $24 \mathrm{~h}$. Based on the aforementioned results, EC109 esophageal cells were treated with $400 \mu \mathrm{mol} / 1 \mathrm{NaHS}$ for $24 \mathrm{~h}$ in all subsequent experiments.

NaHS upregulates the expression levels of HSP9O in EC109 esophageal cells. We observed the effects of NaHS on the expression levels of HSP90. As shown in Fig. 2A and B, exposure of EC109 cells for the indicated time (12 and $24 \mathrm{~h}$ ) to $400 \mu \mathrm{mol} / 1 \mathrm{NaHS}$ markedly enhanced the expression of HSP90, reaching a peak at $24 \mathrm{~h}$.

GA (a specific inhibitor of HSP90 pathway) reduces the cell proliferation in EC109 esophageal cells. EC109 cells were treated with different doses of GA $(10,20,40,60$ and $80 \mu \mathrm{mol} / \mathrm{l}$ ) for $24 \mathrm{~h}$. As shown in Fig. 3A, the doses of GA from 10 to $80 \mu \mathrm{mol} / 1$ markedly reduced cell proliferation, dropping to a bottom at $80 \mu \mathrm{mol} / 1$.

GA alleviates NaHS-induced cell proliferation in EC109 cells. As shown in Fig. 3B, exposure of EC109 cells to $400 \mu \mathrm{mol} / 1$ 
A

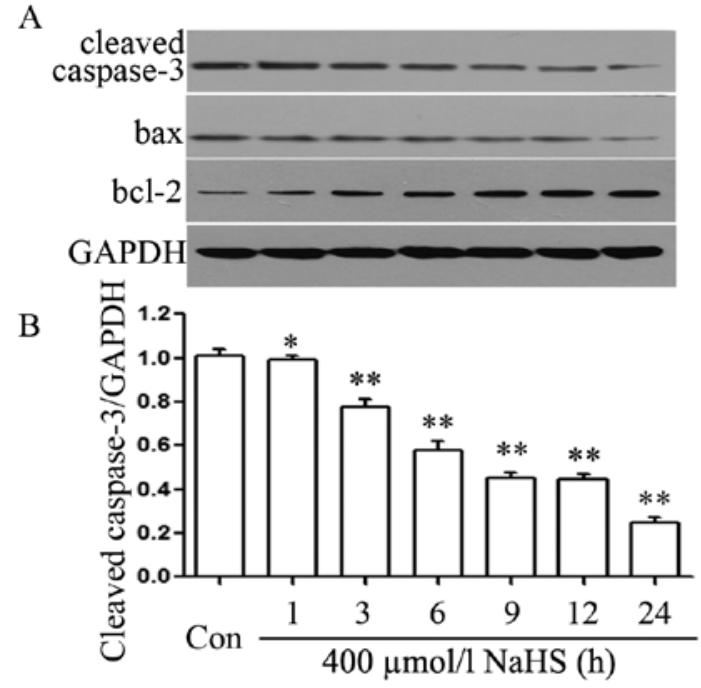

$\mathrm{C}$

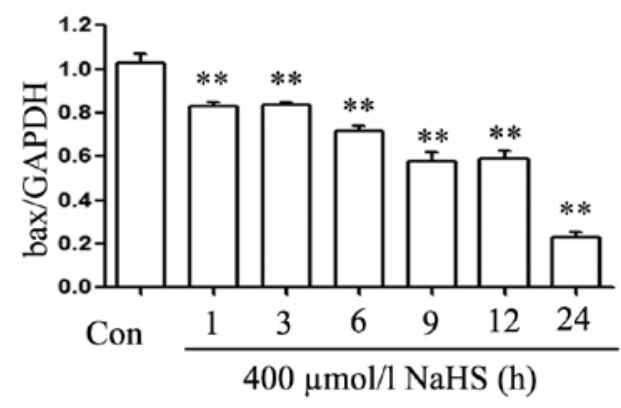

D

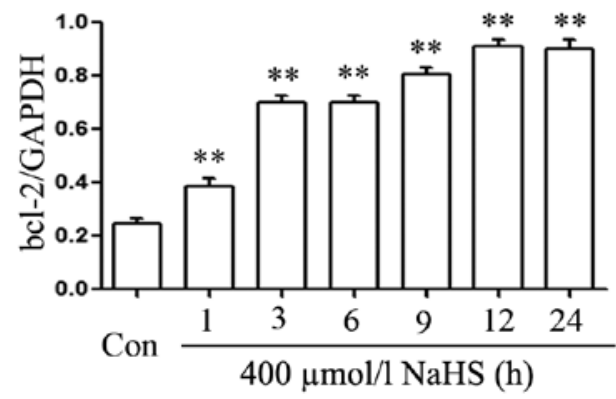

E

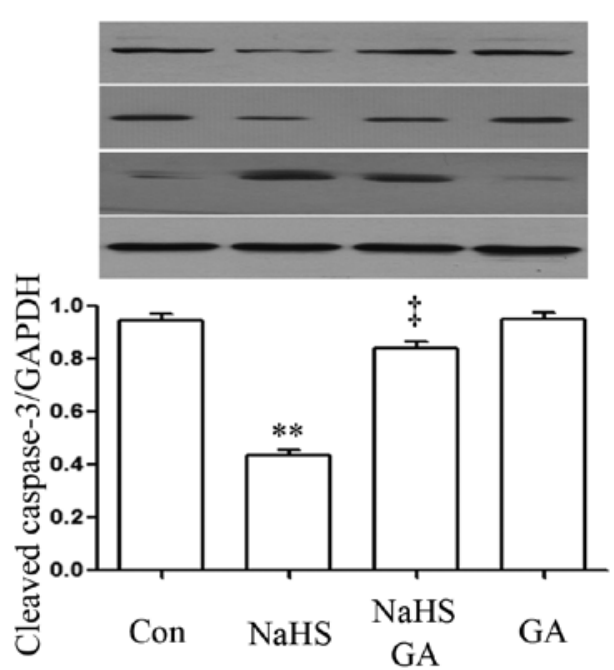

G

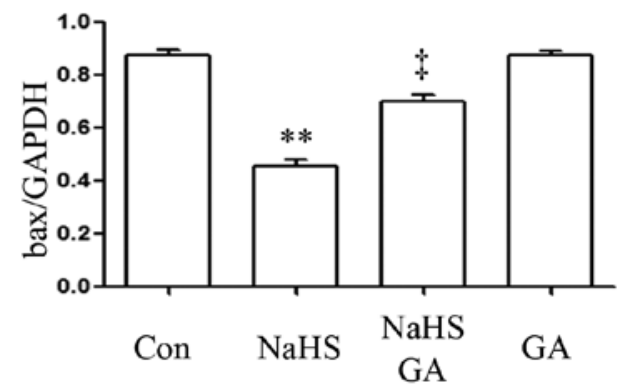

$\mathrm{H}$

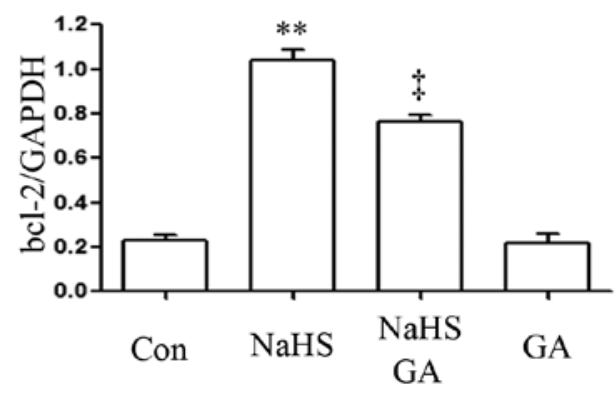

Figure 4. (A) NaHS alleviates the expression level of cleaved caspase-3 and bax, and upregulates the expression levels of bcl-2 in EC109 cells. (B-D) EC109 cells were exposed to $400 \mu \mathrm{mol} / 1$ NaHS for different times (1,3, 6, 9, 12 and $24 \mathrm{~h}$ ). (E) GA upregulates NaHS-induced decreased cleaved caspase-3 and bax, and inhibits NaHS-induced increased bcl-2 expression in EC109 cells. (F-H) EC109 cells were co-conditioned with $400 \mu \mathrm{mol} / 1 \mathrm{NaHS}$ and $20 \mu \mathrm{mol} / 1 \mathrm{GA}$ for $24 \mathrm{~h}$. The expression of cleaved caspase-3, bax and cleaved caspase-3 were measured by western blot assay (A and E). (B-D and F-H) Densitometric analysis for the data (A and E). Data are presented as the means $\pm \mathrm{SEM}(\mathrm{n}=3) .{ }^{* *} \mathrm{P}<0.01 \mathrm{vs}$. the control group; ${ }^{++} \mathrm{P}<0.01$ vs. the NaHS group. Con, the control group; $\mathrm{NaHS}$, a donor of $\mathrm{H}_{2} \mathrm{~S}$.

NaHS for $24 \mathrm{~h}$ induced cell proliferation, leading to an increase in cell viability. However, the increased cell viability was repressed by co-treatment with different doses of GA (a specific inhibitor of HSP90 pathway) for $24 \mathrm{~h}$. As shown in Fig. 3A, at the dose of $10 \mu \mathrm{mol} / 1$, the cell viability did not change. On the contrary, the dose of GA from 20 to $80 \mu \mathrm{mol} / 1$ significantly suppressed the cell proliferation, leading to a decrease in cell viability and reaching the minimum at $20 \mu \mathrm{mol} / 1$. According to the aforementioned results, EC109 cells were co-treated with $400 \mu \mathrm{mol} / 1 \mathrm{NaHS}$ and $20 \mu \mathrm{mol} / \mathrm{l}$ $\mathrm{GA}$ for $24 \mathrm{~h}$ in all following experiments.

NaHS alleviates the expression level of cleaved caspase-3 and bax, and upregulates the expression levels of bcl-2 in
EC109 esophageal cells. In order to observe the effects of $\mathrm{NaHS}$ on the expression levels of cleaved caspase-3, bax and bcl-2 in EC109 cells, EC109 cells were exposed to $400 \mu \mathrm{mol} / 1$ NaHS for different times (1, 3, 6, 9, 12 and $24 \mathrm{~h})$. As shown in Fig. 4A, NaHS significantly enhanced the expression levels of bcl-2 reaching a peak at $12 \mathrm{~h}$, whereas the expression level of caspase- 3 and bax was markedly decreased.

GA inhibits NaHS-induced increased expression levels of bcl-2 and upregulates NaHS-induced decreased caspase-3 expression in EC109 esophageal cells. As shown in Fig. 4E, EC109 cells were exposed to $400 \mu \mathrm{mol} / 1 \mathrm{NaHS}$ for $24 \mathrm{~h}$. The expression levels of bcl-2 were significantly increased; on the contrary, the expression level of caspase- 3 and bax were 
A

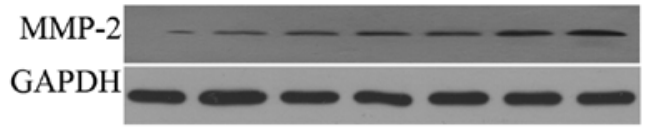

B

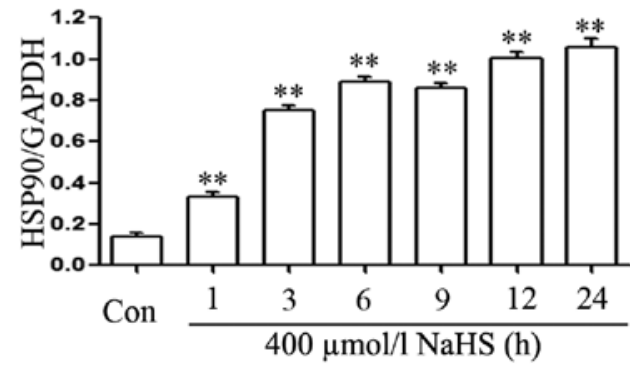

C

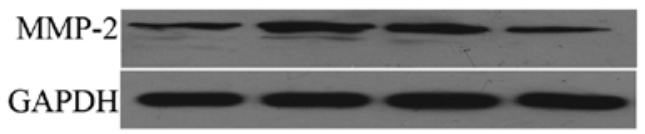

D

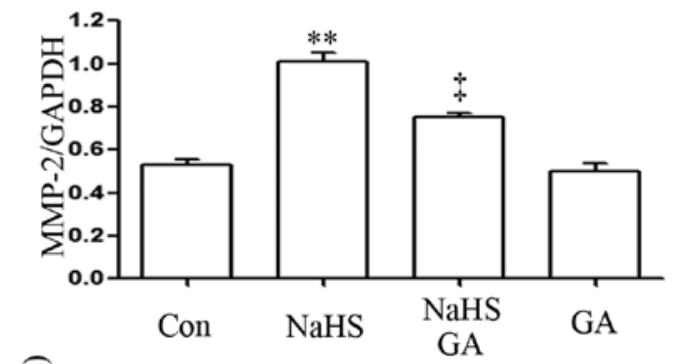

$\mathrm{E}$

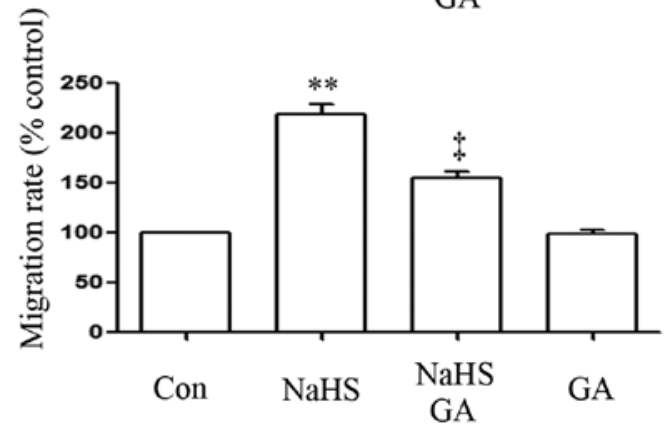

Figure 5. (A) NaHS amplifies the activation of MMP-2 in EC109 cells. (B) EC109 cells were exposed to $400 \mu \mathrm{mol} / 1 \mathrm{NaHS}$ for the indicated times (1, 3, 6, 9, 12 and 24 h). (C) GA inhibits NaHS-induced increased MMP-2 expression in EC109 cells. (D) EC109 cells were co-conditioned with $400 \mu \mathrm{mol} / 1 \mathrm{NaHS}$ and $20 \mu \mathrm{mol} / 1 \mathrm{GA}$ for $24 \mathrm{~h}$. The expression of MMP-2 was measured by western blot assay (A and C). (E) The migration rate was analyzed using a Transwell migration assay and the ImageJ $1.47 \mathrm{i}$ software. The expression of MMP-2 were measured by western blot assay (A and C). (B, D and E) Data are presented as the means \pm SEM $(n=3) .{ }^{* *} \mathrm{P}<0.01$ vs. the control group; ${ }^{++} \mathrm{P}<0.01$ vs. the NaHS group. Con, the control group; NaHS, a donor of $\mathrm{H}_{2} \mathrm{~S}$.

markedly decreased. Notably, co-treatment of EC109 cells with $400 \mu \mathrm{mol} / 1 \mathrm{NaHS}$ and $20 \mu \mathrm{mol} / 1 \mathrm{GA}$ for $24 \mathrm{~h}$ considerably depressed NaHS-induced increased expression levels of bcl-2; however, expression of caspase- 3 and bax was considerably downregulated. Treatment of cells with $20 \mu \mathrm{mol} / 1 \mathrm{GA}$ for $24 \mathrm{~h}$ did not alter the basal expression levels of caspase-3, bax or bcl-2.

NaHS upregulates the expression level of MMP-2. In order to observe the effects of NaHS on the expression levels of MMP-2 in EC109 cells, EC109 cells were exposed to $400 \mu \mathrm{mol} / 1 \mathrm{NaHS}$ for different times (1, 3, 6, 9, 12 and $24 \mathrm{~h})$. As shown in Fig. 5A, NaHS significantly enhanced the expression levels of MMP-2,

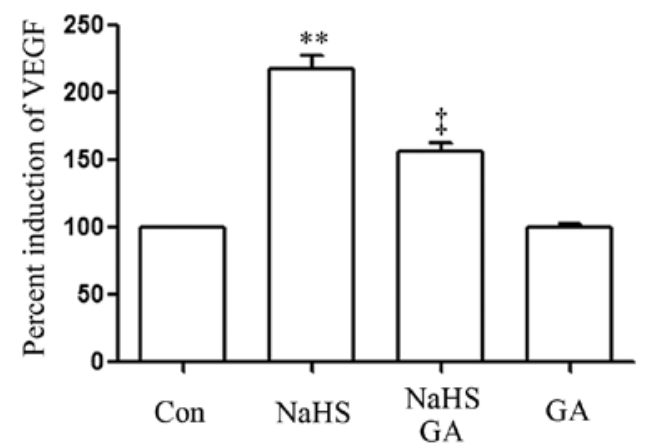

Figure 6. GA suppresses NaHS-induced upregulated production of VEGF in EC109 cells. EC109 cells were co-conditioned with $500 \mu \mathrm{mol} / 1 \mathrm{NaHS}$ and $20 \mu \mathrm{mol} / 1 \mathrm{GA}$ for $24 \mathrm{~h}$. The production of vascular endothelial growth factor (VEGF) was tested by enzyme-linked immunosorbent assay (ELISA). Data are presented as the means $\pm \operatorname{SEM}(n=3) .{ }^{* *} \mathrm{P}<0.01$ vs. the control group; ${ }^{++} \mathrm{P}<0.01$ vs. the NaHS group. Con, the control group; NaHS, a donor of $\mathrm{H}_{2} \mathrm{~S}$.

which peaked at $24 \mathrm{~h}$. Notably, co-treatment of EC109 cells with $400 \mu \mathrm{mol} / 1 \mathrm{NaHS}$ and $20 \mu \mathrm{mol} / \mathrm{l} \mathrm{GA}$ for $24 \mathrm{~h}$ considerably depressed NaHS-induced increased expression levels of MMP-2. Treatment of cells with $20 \mu \mathrm{mol} / 1 \mathrm{GA}$ for $24 \mathrm{~h}$ did not alter the basal expression levels of MMP-2.

The migration rate and Transwell migration assay. As shown in Fig. 5E, NaHS strengthened the migration rate in EC109 esophageal cells while GA depressed NaHS-induced increased migration rate. Treatment of cells with $20 \mu \mathrm{mol} / 1$ GA for $24 \mathrm{~h}$ did not alter the migration rate compared with control group.

GA suppresses NaHS-induced upregulated production of VEGF in EC109 esophageal cells. As shown in Fig. 6, the level of VEGF was markedly increased in NaHS-induced EC109 cells compared with the control group $(\mathrm{P}<0.01)$. However, the increased level of VEGF was significantly suppressed by co-treatment with GA and NaHS.

$\mathrm{H}_{2} \mathrm{~S}$ demonstrates proliferation, anti-apoptosis, angiogenesis and migration effects on EC109 esophageal cells via amplifying the activation of HSP90 pathway. We found that NaHS upregulated HSP90 activity resulting in an elevated rate of $\mathrm{H}_{2} \mathrm{~S}$ production level, which in turn modulated protein expressions of caspase-3, bax, bcl-2, MMP-2 and VEGF. The downregulated caspase- 3 and bax directly induced anti-apoptosis, led to decreased apoptosis and increased cell viability of EC109 cells. MMP-2 contributes to cancer cell invasion and migration. The increased production of VEGF stimulates angiogenesis, promoting the supply of nutrients and blood to the tumor. Conversely, the above properties of $\mathrm{H}_{2} \mathrm{~S}$ were significantly inhibited by the co-condition of $400 \mu \mathrm{mol} / 1$ NaHS and $20 \mu \mathrm{mol} / \mathrm{l} \mathrm{GA}$ for $24 \mathrm{~h}$.

\section{Discussion}

In the present study, we demonstrated a novel finding of $\mathrm{H}_{2} \mathrm{~S}$ on esophageal EC109 cells and provided evidence to reveal its potential mechanisms. These findings support our hypothesis that preconditioning with exogenous $\mathrm{H}_{2} \mathrm{~S}$ mediates 
proliferation, anti-apoptotic, angiopoiesis and migration effects in esophageal cancer. The molecular mechanisms of $\mathrm{H}_{2} \mathrm{~S}$ are not yet fully understood. It is known that $\mathrm{H}_{2} \mathrm{~S}$ is produced in the body mainly by two crucial enzymes, CBS and CSE, which are mainly found in the central nervous system (CNS) (32). A recent study emphasized that $\mathrm{H}_{2} \mathrm{~S}$ played an important role in various physiological and pathological processes of the nervous system as a neuromodulator and neuroprotectant (33). Furthermore, $\mathrm{H}_{2} \mathrm{~S}$ could exert protection to nerve cancer cells, such as PC12 cells (34). However, the performance of $\mathrm{H}_{2} \mathrm{~S}$ on the cancer cells are comparatively complicated and extremely controversial. On the one hand, $\mathrm{H}_{2} \mathrm{~S}$ has shown its anticancer ability based on anti-inflammatory effect, antiapoptosis and activation of some signal pathways $(35,36)$. On the other hand, $\mathrm{H}_{2} \mathrm{~S}$ can exert totally opposite properties via amplifying the activation of $N F-\kappa B$ pathway (30) and p38 MAPK/ERK1/2-COX-2 pathways (31) in other cancer cells. In order to confirm our hypothesis, EC109 cells were treated with $\mathrm{NaHS}$ (a donor of $\mathrm{H}_{2} \mathrm{~S}$ ) and some typical pathwayrelated biomarkers were detected. Unexpectedly, we found two interesting results. Firstly, the optimal concentration of NaHS that induced maximal effect of proliferation was $400 \mu \mathrm{mol} / 1$, which was in the range of physiological doses of $\mathrm{H}_{2} \mathrm{~S}(0.2-1$ mmol/l). This indicated that $\mathrm{H}_{2} \mathrm{~S}$ may participate in the esophageal cancer growth. Secondly, previous studies have suggested that HSPs can prevent pro-apoptotic signaling and apoptosis (10). Therefore, it is necessary to assess apoptotic factors and apoptosis in EC109 cells. Treatment of cells with $400 \mu \mathrm{mol} / 1 \mathrm{NaHS}$ for $24 \mathrm{~h}$ markedly diminished cell apoptosis by upregulating the expression of bcl-2 and decreasing the expression of caspase- 3 and bax, which are pro-apoptotic Bcl-2 family proteins. Moreover, the aforementioned NaHS-induced effects were inhibited by GA. HSPs can inhibit the activity of pro-apoptotic Bcl-2 proteins to prevent permeabilization of the outer mitochondrial membrane and release of apoptogenic factors (10). The disruption of apoptosome formation represents another mechanism by which HSPs can prevent caspase activation and induction of apoptosis. The aforementioned results were consistent with previous studies (15-17). These data demonstrated that $\mathrm{H}_{2} \mathrm{~S}$ exerted its cell proliferation and anti-apoptosis effects in EC109 cells via activating the HSP90 pathway, and $\mathrm{H}_{2} \mathrm{~S}$ may be involved in esophageal cancer growth under physiological conditions. Given that the previous study showed that $\mathrm{H}_{2} \mathrm{~S}$-protected $\mathrm{PC} 12$ cells from formaldehyde induced apoptosis (34), our findings imply that $\mathrm{H}_{2} \mathrm{~S}$ exerts a cytoprotective effect for EC109 cells.

A large number of experiments have shown that $\mathrm{H}_{2} \mathrm{~S}$ can contribute to VEGF production (37-41). The present study also found that $\mathrm{H}_{2} \mathrm{~S}$ significantly increased the production of VEGF in EC109 cells, and the effect was similarly suppressed by the specific HSP90 pathway inhibitor. VEGF is one of the most potent and pivotal angiogenic factors, and is crucial for the persistent proliferation and metastasis of tumor cells (42). Therefore, we hypothesized that $\mathrm{H}_{2} \mathrm{~S}$ promotes the supply of blood and nutrients to the tumor via angiogenesis effect. Further studies are needed to explore our hypothesis in vivo. It is well known that tumor invasion and metastasis require increased expressions of MMPs. Among the MMPs, MMP-2 and MMP-9 have been thought to be key enzymes in this process since they degrade type IV collagen, which is one of the important components of extracellular matrix (43). Growing evidence reveals that the upregulated expression of MMPs, particularly the gelatinase (MMP-2 and MMP-9), is closely associated with metastasis potential in several types of carcinomas (44-47). The present study demonstrated that HSP90 activation strongly increases the expression of MMP-2 protein in EC109 cells, which indicated that $\mathrm{H}_{2} \mathrm{~S}$ was involved in EC109 cell invasion and migration.

To investigate the complicated mechanism for NaHS induced pro-proliferative effect, anti-apoptosis, angiogenesis and migration in EC109 cells, we studied the HSP90 pathway, which has been previously demonstrated, linked to cancer progression by regulation of cell proliferation, signaling and apoptosis (15-17). It has been reported that HSP90 can be activated by various stimuli both in normal and in cancer cells (10). Herein, we found that NaHS activated HSP90 pathway in EC109 cells. Notably, GA, an inhibitor of HSP90, blocked NaHSinduced HSP90 pathway activation by decreasing expression levels of bcl-2, MMP-2 and VEGF, and increasing caspase-3 and bax expression. These results suggest that HSP90 activation is necessary in NaHS-induced EC109 cell progression.

In conclusion, $\mathrm{H}_{2} \mathrm{~S}$-induced cell proliferation, anti-apoptosis, angiogenesis and migration in EC109 esophageal cells. These effects may be mediated by the activation of HSP90 pathway, leading to overexpression levels of MMP-2, bcl-2 and VEGF, downregulation of caspase-3 and bax, increased cell viability, and decreased number of apoptotic cells. In esophageal cancer, the findings provide novel insight into a unified concept and identify $\mathrm{H}_{2} \mathrm{~S}$ as an endogenous tumor-promoting factor and anticancer drug target. The deeper mechanism of $\mathrm{H}_{2} \mathrm{~S}$ in EC109 esophageal cells is still unclear and needs to be further investigated.

\section{References}

1. Kamangar F, Dores GM and Anderson WF: Patterns of cancer incidence, mortality, and prevalence across five continents: Defining priorities to reduce cancer disparities in different geographic regions of the world. J Clin Oncol 24: 2137-2150, 2006 .

2. Wheeler JB and Reed CE: Epidemiology of esophageal cancer. Surg Clin North Am 92: 1077-1087, 2012.

3. Hongo M, Nagasaki Y and Shoji T: Epidemiology of esophageal cancer: Orient to Occident. Effects of chronology, geography and ethnicity. J Gastroenterol Hepatol 24: 729-735, 2009.

4. Ferlay J, Shin HR, Bray F, Forman D, Mathers C and Parkin DM: Estimates of worldwide burden of cancer in 2008: GLOBOCAN 2008. Int J Cancer 127: 2893-2917, 2010.

5. Kaneko K, Kumekawa Y, Makino R, Nozawa H, Hirayama Y, Kogo M, Konishi K, Katagiri A, Kubota Y, Muramoto T, et al: EGFR gene alterations as a prognostic biomarker in advanced esophageal squamous cell carcinoma. Front Biosci 15: 65-72, 2010.

6. Delektorskaya VV, Chemeris GY, Zavalishina LE, Ryazantseva AA, Grigorchuk AY, Kononets PV and Davydov MI: Squamous cell carcinoma of the esophagus: Evaluation of the status of epidermal growth factor receptors (EGFR and HER-2) by immunohistochemistry and in situ hybridization. Bull Exp Biol Med 149: 615-620, 2010.

7. Berg D, Wolff C, Langer R, Schuster T, Feith M, SlottaHuspenina J, Malinowsky K and Becker KF: Discovery of new molecular subtypes in oesophageal adenocarcinoma. PLoS One 6: e23985, 2011

8. Langer R, Ott K, Specht K, Becker K, Lordick F, Burian M, Herrmann K, Schrattenholz A, Cahill MA, Schwaiger M, et al: Protein expression profiling in esophageal adenocarcinoma patients indicates association of heat-shock protein 27 expression and chemotherapy response. Clin Cancer Res 14: 8279-8287, 2008. 
9. Morimoto RI: Cells in stress: Transcriptional activation of heat shock genes. Science 259: 1409-1410, 1993.

10. Beere HM: 'The stress of dying': The role of heat shock proteins in the regulation of apoptosis. J Cell Sci 117: 2641-2651, 2004.

11. Mehta TA, Greenman J, Ettelaie C, Venkatasubramaniam A, Chetter IC and McCollum PT: Heat shock proteins in vascular disease - a review. Eur J Vasc Endovasc Surg 29: 395-402, 2005.

12. Cohen SM, Mukerji R, Samadi AK, Zhang X, Zhao H, Blagg BS and Cohen MS: Novel C-terminal Hsp90 inhibitor for head and neck squamous cell cancer (HNSCC) with in vivo efficacy and improved toxicity profiles compared with standard agents. Ann Surg Oncol 19 (Suppl 3): S483-S490, 2012.

13. Drecoll E, Nitsche U, Bauer K, Berezowska S, SlottaHuspenina J, Rosenberg R and Langer R: Expression analysis of heat shock protein 90 (HSP90) and Her2 in colon carcinoma. Int J Colorectal Dis 29: 663-671, 2014.

14. Jego G, Hazoumé A, Seigneuric R and Garrido C: Targeting heat shock proteins in cancer. Cancer Lett 332: 275-285, 2013.

15. Lu X, Xiao L, Wang L and Ruden DM: Hsp90 inhibitors and drug resistance in cancer: The potential benefits of combination therapies of Hsp90 inhibitors and other anti-cancer drugs. Biochem Pharmacol 83: 995-1004, 2012.

16. Den RB and Lu B: Heat shock protein 90 inhibition: Rationale and clinical potential. Ther Adv Med Oncol 4: 211-218, 2012

17. Chehab M, Caza T, Skotnicki K, Landas S, Bratslavsky G Mollapour M and Bourboulia D: Targeting Hsp90 in urothelial carcinoma. Oncotarget 6: 8454-8473, 2015.

18. Wang R: Two's company, three's a crowd: Can $\mathrm{H}_{2} \mathrm{~S}$ be the third endogenous gaseous transmitter? FASEB J 16: 1792-1798, 2002

19. Kilburn KH, Thrasher JD and Gray MR: Low-level hydrogen sulfide and central nervous system dysfunction. Toxicol Ind Health 26: 387-405, 2010

20. Guidotti TL: Hydrogen sulfide: Advances in understanding human toxicity. Int J Toxicol 29: 569-581, 2010.

21. Han YF, Huang X, Guo X, Wu YS, Liu DH, Lu HL, Kim YC and Xu WX: Evidence that endogenous hydrogen sulfide exerts an excitatory effect on gastric motility in mice. Eur J Pharmacol 673: 85-95, 2011.

22. Schicho R, Krueger D, Zeller F, Von Weyhern CW, Frieling T, Kimura H, Ishii I, De Giorgio R, Campi B and Schemann M: Hydrogen sulfide is a novel prosecretory neuromodulator in the Guinea-pig and human colon. Gastroenterology 131: 1542-1552, 2006.

23. Cai WJ, Wang MJ, Ju LH, Wang C and Zhu YC: Hydrogen sulfide induces human colon cancer cell proliferation: Role of Akt, ERK and p21. Cell Biol Int 34: 565-572, 2010.

24. Cao Q, Zhang L, Yang G, Xu C and Wang R: Butyrate-stimulated $\mathrm{H}_{2} \mathrm{~S}$ production in colon cancer cells. Antioxid Redox Signal 12 1101-1109, 2010

25. Du SX, Xiao J, Guan F, Sun LM, Wu WS, Tang H, Du JB, Tang CS and Jin HF: Predictive role of cerebrospinal fluid hydrogen sulfide in central nervous system leukemia. Chin Med J 124: 3450-3454, 2011.

26. Levine J, Ellis CJ, Furne JK, Springfield J and Levitt MD Fecal hydrogen sulfide production in ulcerative colitis. Am J Gastroenterol 93: 83-87, 1998.

27. Pupo E, Pla AF, Avanzato D, Moccia F, Cruz JE, Tanzi F, Merlino A, Mancardi D and Munaron L: Hydrogen sulfide promotes calcium signals and migration in tumor-derived endothelial cells. Free Radic Biol Med 51: 1765-1773, 2011.

28. Rose P, Moore PK, Ming SH, Nam OC, Armstrong JS and Whiteman M: Hydrogen sulfide protects colon cancer cells from chemopreventative agent beta-phenylethyl isothiocyanate induced apoptosis. World J Gastroenterol 11: 3990-3997, 2005.

29. Szabo C, Coletta C, Chao C, Módis K, Szczesny B, Papapetropoulos A and Hellmich MR: Tumor-derived hydrogen sulfide, produced by cystathionine- $\beta$-synthase, stimulates bioenergetics, cell proliferation, and angiogenesis in colon cancer. Proc Natl Acad Sci USA 110: 12474-12479, 2013.

30. Zhen Y, Pan W, Hu F, Wu H, Feng J, Zhang Y and Chen J: Exogenous hydrogen sulfide exerts proliferation/anti-apoptosis/angiogenesis/migration effects via amplifying the activation of NF- $\mathrm{BB}$ pathway in PLC/PRF/5 hepatoma cells. Int J Oncol 46: 2194-2204, 2015.
31. Zhen Y, Zhang W, Liu C, He J, Lu Y, Guo R, Feng J, Zhang Y and Chen J: Exogenous hydrogen sulfide promotes C6 glioma cell growth through activation of the p38 MAPK/ERK1/2-COX-2 pathways. Oncol Rep 34: 2413-2422, 2015.

32. Tan BH, Wong PT and Bian JS: Hydrogen sulfide: A novel signaling molecule in the central nervous system. Neurochem Int 56: 3-10, 2010.

33. Zhang X and Bian JS: Hydrogen sulfide: A neuromodulator and neuroprotectant in the central nervous system. ACS Chem Neurosci 5: 876-883, 2014.

34. Jiang JM, Zhou CF, Gao SL, Tian Y, Wang CY, Wang L, Gu HF and Tang XQ: BDNF-TrkB pathway mediates neuroprotection of hydrogen sulfide against formaldehyde-induced toxicity to PC12 cells. PLoS One 10: e0119478, 2015.

35. Kashfi K: Anti-cancer activity of new designer hydrogen sulfide-donating hybrids. Antioxid Redox Signal 20: 831-846, 2014.

36. Ma K, Liu Y, Zhu Q, Liu CH, Duan JL, Tan BK and Zhu YZ: $\mathrm{H}_{2} \mathrm{~S}$ donor, S-propargyl-cysteine, increases CSE in SGC-7901 and cancer-induced mice: Evidence for a novel anti-cancer effect of endogenous $\mathrm{H}_{2} \mathrm{~S}$ ? PLoS One 6: e20525, 2011.

37. Bir SC, Kolluru GK, McCarthy P, Shen X, Pardue S, Pattillo CB and Kevil CG: Hydrogen sulfide stimulates ischemic vascular remodeling through nitric oxide synthase and nitrite reduction activity regulating hypoxia-inducible factor- $1 \alpha$ and vascular endothelial growth factor-dependent angiogenesis. J Am Heart Assoc 1: e004093, 2012.

38. Holwerda KM, Burke SD, Faas MM, Zsengeller Z, Stillman IE, Kang PM, van Goor H, McCurley A, Jaffe IZ, Karumanchi SA, et al: Hydrogen sulfide attenuates sFlt1-induced hypertension and renal damage by upregulating vascular endothelial growth factor. J Am Soc Nephrol 25: 717-725, 2014.

39. Köhn C, Dubrovska G, Huang Y and Gollasch M: Hydrogen sulfide: Potent regulator of vascular tone and stimulator of angiogenesis. Int J Biomed Sci 8: 81-86, 2012.

40. Polhemus DJ, Kondo K, Bhushan S, Bir SC, Kevil CG, Murohara T, Lefer DJ and Calvert JW: Hydrogen sulfide attenuates cardiac dysfunction after heart failure via induction of angiogenesis. Circ Heart Fail 6: 1077-1086, 2013.

41. Tao BB, Liu SY, Zhang CC, Fu W, Cai WJ, Wang Y, Shen Q, Wang MJ, Chen Y, Zhang LJ, et al: VEGFR2 functions as an $\mathrm{H}_{2} \mathrm{~S}$-targeting receptor protein kinase with its novel Cys1045-Cys1024 disulfide bond serving as a specific molecular switch for hydrogen sulfide actions in vascular endothelial cells. Antioxid Redox Signal 19: 448-464, 2013.

42. Leung WK, To KF, Go MY, Chan KK, Chan FK, Ng EK, Chung SC and Sung JJ: Cyclooxygenase-2 upregulates vascular endothelial growth factor expression and angiogenesis in human gastric carcinoma. Int J Oncol 23: 1317-1322, 2003.

43. Egeblad M and Werb Z: New functions for the matrix metalloproteinases in cancer progression. Nat Rev Cancer 2: 161-174, 2002.

44. Jones JL, Shaw JA, Pringle JH and Walker RA: Primary breast myoepithelial cells exert an invasion-suppressor effect on breast cancer cells via paracrine down-regulation of MMP expression in fibroblasts and tumour cells. J Pathol 201: 562-572, 2003.

45. Li C, Li F, Zhao K, Yao J, Cheng Y, Zhao L, Li Z, Lu N and Guo Q: LFG-500 inhibits the invasion of cancer cells via downregulation of PI3K/AKT/NF-кB signaling pathway. PLoS One 9: e91332, 2014

46. Puzovic V, Brcic I, Ranogajec I and Jakic-Razumovic J: Prognostic values of ETS-1, MMP-2 and MMP-9 expression and co-expression in breast cancer patients. Neoplasma 61: 439-446, 2014.

47. Ruan M, Zhang Z, Li S, Yan M, Liu S, Yang W, Wang L and Zhang C: Activation of Toll-like receptor-9 promotes cellular migration via up-regulating MMP-2 expression in oral squamous cell carcinoma. PLoS One 9: e92748, 2014. 